\title{
Involvement of immune cells in regulation of ovarian function
}

\author{
J. L. Pate \\ Ohio State University, Department of Animal Sciences, 2027 Coffey Road, Columbus, OH 43210, \\ USA
}

\begin{abstract}
Primary cultures of luteal cells have been used to determine both acute and chronic effects of cytokines on luteal cell function and viability. Gonadotrophin-stimulated progesterone production is inhibited by interleukin I $\beta$ (IL-I $\beta$ ), tumour necrosis factor $\alpha$ (TNF- $\alpha$ ), or gamma-interferon (IFN- $\gamma$ ), the last two cytokines being more effective than IL- I. In contrast, all three cytokines are potent stimulators of prostaglandin production by these cells. The mechanism by which prostaglandin synthesis is enhanced may differ slightly for each cytokine. In luteal cells, TNF- $\alpha$ appears to act primarily through stimulation of phospholipase $A_{2}$, whereas IL-I $\beta$ may activate phospholipase $C$ and prostaglandin endoperoxide synthase (PGS) in addition to phospholipase $\mathrm{A}_{2}$. The mechanism of action of IFN- $\gamma$ has not yet been determined. In addition to the observed functional effects, cytokines may also promote cell death during luteal regression. Although the three cytokines mentioned have little or no effect on viability of cultured luteal cells when administered separately, combined treatment with TNF- $\alpha$ and IFN- $\gamma$ results in a substantial decrease in the number of viable cells. Inhibition of cytokine-stimulated prostaglandin production does not alter the cytotoxic effect of these cytokines. Expression of major histocompatibility (MHC) class I molecules on luteal cells is enhanced, and MHC class II molecules are induced, by exposure to IFN- $\gamma$. This is especially intriguing, as MHC class II expression increases before luteal regression in vivo, and is suppressed in early pregnancy. In summary, evidence is rapidly accumulating that supports the hypothesis that the function or structural integrity of huteal cells may be modulated by resident immune cells. Future research will probably address how these local events are hormonally controlled, and if they can be modified to regulate corpus luteum function.
\end{abstract}

\section{Introduction}

The coordinated function of reproductive organs is regulated systemically by the controlled release of various hormones. The response of a target tissue to these hormones can be modified by local factors which have autocrine or paracrine effects. Much attention has been focused on the hormones and factors that act on, or are produced by, reproductive cells, such as the steroidogenic cells in the ovary. More recently, it has been appreciated that reproductive tissues are composed of a heterogeneous population of cells, which may be involved in modulating the activity of the relevant reproductive cell type. The function of steroidogenic cells may be altered by endothelial cells and fibroblasts, through secretion of growth factors or by direct cell-cell contacts. In many tissues, resident immune cells may also have a role in the regulation of that tissue. Haematopoietic cells are found in the extravascular tissue of the ovary, uterus and testis (Hill and Anderson, 1990). The products of these cells, termed cytokines, have been 
localized in uterine and trophoblastic tissues (Hunt et al., 1992, 1993), and may be involved in embryonic-uterine signalling at the time of implantation. The effects of one cytokine, interleukin-1 (IL-1), on hypothalamic-pituitary function are well documented (Sapolsky et al, 1987). This review will focus on immune cells and cytokine actions in the ovary, with emphasis on the corpus luteum, particularly luteal regression. The reader is referred to other recent reviews on this subject (Pate, 1994; Pate and Townson, 1994).

\section{Immune Cells and Their Products}

Leukocytic cells which coordinate and carry out specific immune responses can be generally classified into three categories. Macrophages are phagocytic cells that process proteins to be presented to I cells, and serve as early activators of the immune response. In humoral immune responses, B cells, which are antibody-producing cells, can also present antigens to $T$ cells. $T$ cells are antigen-restricted cells: differentiation and proliferation of these cells occur only in response to recognition of antigenic peptide which is presented in association with a major histocompatibility ( $\mathrm{MHC}$ ) molecule on the cell surface. Cytotoxic $\mathrm{T}$ cells $\left(\mathrm{T}_{\mathrm{C}}\right)$ recognize antigens in association with $\mathrm{MHC}$ class 1 molecules, and when activated, cause direct damage to cell membranes leading to cytolysis. MHC class II molecules are recognized by $T$ helper $\left(T_{H}\right)$ cells, which then secrete a variety of cytokines that activate $B$ cells or $T_{C}$ cells. Subclasses of $T_{H}$ cells can be recognized on the basis of the cytokines that they secrete. Cells of the $\mathrm{T}_{\mathrm{H}} \mathrm{I}$ subclass produce IL-2, gamma-interferon (IFN- $\gamma$ ) and tumour necrosis factor (TNF). In contrast, $\mathrm{T}_{\mathrm{H}} 2$ cells produce IL-4, IL- 5 and IL-6 (Abbas et al, 1991). Interestingly $\mathrm{T}_{\mathrm{H}} \mathrm{I}$ cells, but not $\mathrm{T}_{\mathrm{H}} 2$ cells, may also mediate target cell killing. Inflammatory responses involve other cell types, such as eosinophils, neutrophils and basophils. The intensity of an inflammatory response can be regulated by immune response cells.

Macrophages and $\mathrm{T}$ cells are present in both the follicular and luteal compartments of the ovary. Macrophages are present in the follicles of pigs and sheep, and their numbers increase at the time of ovulation (Cavender and Murdoch, 1988; Standaert et al., 1990). T cells are also present in follicle walls of rats and humans; however, there are fewer T cells than macrophages (Brannstrom and Norman, 1993). Both macrophages and lymphocytes are present in corpora lutea throughout the luteal phase (Lobel and Levy, 1968; Brannstrom et al., 1994a). In the rabbit corpus luteum, the number of lymphocytes remains constant, but the number of macrophages increases before the onset of luteolysis (Bagavandoss et al., 1988). An early study in cows showed that fewer immune cells infiltrate the corpus luteum during early pregnancy than in the nonfertile cycle (Lobel and Levy, 1968).

Cytokines are soluble proteins which have been primarily viewed as autocrine or paracrine factors acting within the immune system. However, it is now recognized that some of the cytokines are also produced by, and can act on, non-immune cells. The cytokines that have been implicated in ovarian function are IL-1, IL-2, TNF- $\alpha$, IFN- $\gamma$, IFN- $\alpha$ and granulocyte-macrophage colony-stimulating factor (GM-CSF).

\section{Actions of Cytokines in the Ovary}

Before purified or recombinant cytokines were available, it was recognized that progesterone production by granulosa cells could be altered by leukocyte secretions. Lymphocyte-conditioned medium stimulates progesterone production by cultured rat and human granulosa cells (Hughes et al., 1991; Emi et al., 1991). Co-culture of lymphocytes with pig granulosa cells results in enhanced progesterone secretion if the granulosa cells are derived from large, but not from small, follicles. However, monocytes stimulate progesterone production by granulosa cells from both small and large follicles (Standaert et al., 1990). However, it is not possible to determine from these studies whether the effects were due to actions of cytokines or other secreted products, such as prostaglandins, growth factors, or gonadotrophin-like substances.

The effects of purified preparations of specific cytokines on follicular cells tend to be inhibitory, although this may depend on the state of differentiation of the granulosa cells. In most studies, 
FSH-stimulated steroidogenesis and induction of LH receptors was inhibited by IL-1 $\beta$, TNF- $\alpha$ or IFN- $\gamma$ (Gottschall et al., 1987; Gorospe et al., 1988; Darbon et al., 1989; Roby and Terranova, 1990). In pig granulosa cells collected from small follicles, FSH-stimulated oestradiol production is inhibited by IL-1 $\beta$, IL-2, IL- 6 , TNF- $\alpha$, IFN- $\gamma$ and IFN- $\alpha$, whereas cells from large follicles are sensitive only to IFN- $\alpha$ (Spicer and Alpizar, 1994). Thus, cytokines seem to suppress differentiation of granulosa cells, and less differentiated cells are more sensitive to the effects of cytokines than are more differentiated cells. There is some evidence that cytokines, particularly IL-I $\beta$, may be involved in the ovulatory process. Periovulatory ovine follicles secrete a chemoattractant for leukocytes (Murdoch and McCormick, 1989), and the ovulation rate of perfused rat ovaries is enhanced in the presence of leukocytes (Hellberg et al., 1991). Brannstrom et al. (1993a) reported that IL-1 $\beta$ can cause ovulation in the rat ovary perfused in vitro, and greatly enhances the $\mathrm{LH}$-induced ovulation rate. The potential role of cytokines in ovulation has recently been reviewed by Brannstrom and Norman (1993).

Very little is known about the role of cytokines in luteinization and early luteal function, although leukocytes are often involved in tissue remodelling events, which occur at this time (Smith et al., 1994). In sheep, large numbers of eosinophils, but small numbers of neutrophils and lymphocytes were found in the developing corpus luteum (Cavender and Murdoch, 1988). Progesterone synthesis is enhanced by TNF- $\alpha$ in rat thecal (Roby and Terranova, 1990; Brannstrom et al., 1993b) and human luteinized granulosa (Yan ef al, 1993) cells, and by IL-1 $\beta$ in hamster thecal cells (Nakamura et al., 1990). Yan ef al. (1993) proposed that TNF- $\alpha$ promotes formation of the corpus luteum by increasing proliferation and steroidogenesis of luteinizing granulosa cells. Again, the effects of cytokines may depend on the state of differentiation of the target cell as well as the presence or absence of other growth factors and regulators of the differentiative process.

If cytokines play a role in follicular or luteal function, it is a prerequisite that they be present in the tissue. Immunoreactive TNF- $\alpha$ has been identified in the follicular and luteal compartments of the bovine ovary and is secreted by granulosa cells (Roby and Terranova, 1989). Ji et al. (I991) detected TNF- $\alpha$ mRNA and bioactivity in regressing ovine corpora lutea, but only after the initial fall in progesterone. Preliminary observations in our laboratory indicate that mRNA encoding TNF- $\alpha$ is present in the bovine corpus luteum before luteolysis. The ovary is also a source of IL-1 and GM-CSF (Ziltener et al, 1993; Brannstrom et al, 1994b).

\section{Role of Immune Cells and Cytokines in Luteolysis}

Most of the work in ruminants on immune cell and cytokine effects on the ovary has concerned their potential role in luteal regression. As mentioned previously, leukocytes are present in the corpus luteum or infiltrate the tissue at about the time of luteolysis. Clearly, these cells are actively involved in the destruction of luteal cells after they are no longer functional. Recently, however, it has been suggested that immune cells or cytokines may be involved in functional changes that are associated with luteal regression. The first indication that an intact immune system may be necessary for normal cyclic ovarian function was the inhibition of ovulation and the development of a constant dioestrus in rats treated with antithymocyte serum (Bukovsky et al., 1977). It is likely that the effects of the immune system are mediated by alterations of the hypothalamo-pituitary-gonadal axis, as well as through direct interactions with ovarian cells.

We have used primary cultures of bovine luteal cells to determine whether cytokines could directly influence luteal cell functions. These cells were all maintained in serum-free culture medium supplemented with insulin, transferrin and selenium. In an initial study, we reported that IL-I $\beta$ did not significantly affect basal progesterone production by luteal cells (Nothnick and Pate, 1990). However, in subsequent experiments, we found that IL-1 $\beta$ does inhibit LH-stimulated steroidogenesis (Fig. I). Pitzel et al. (1993) reported that IL-I decreased both basal and LH-stimulated progesterone in pig luteal cells. The different effects of $\mathrm{L}-\mathrm{I}$ on basal progesterone in these two studies could be due to the presence of serum in the porcine cell cultures, which may have provided additional growth factors or hormones which were antagonized by IL-1. The most profound effect of IL-1B that was observed in bovine luteal cell cultures was the stimulation of prostaglandin synthesis. Treatment with IL-I $\beta$ resulted in large, 


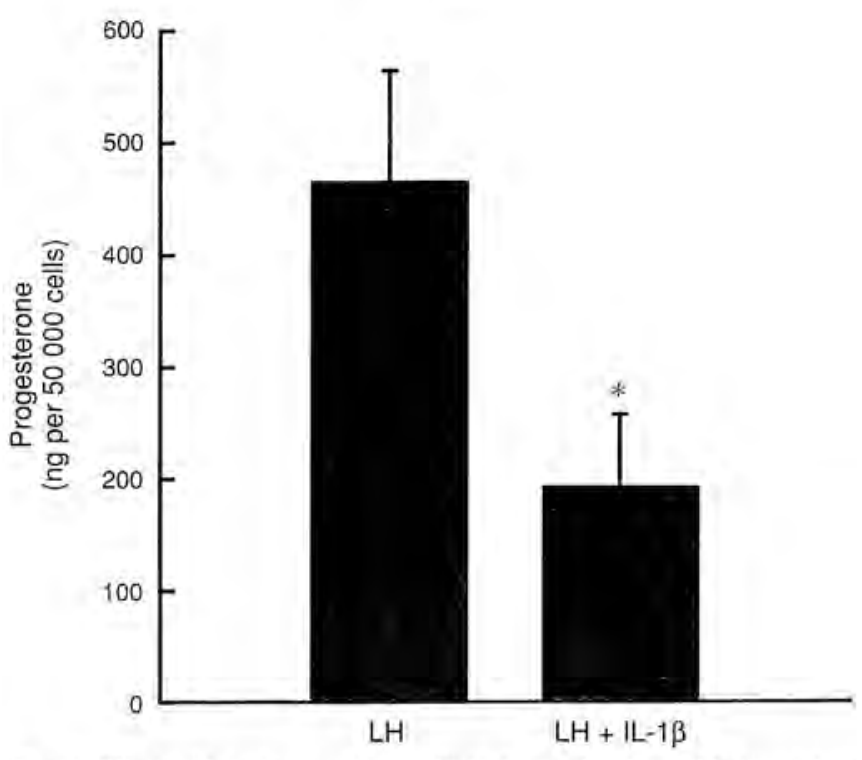

Fig. 1. Effect of interleukin I $(\mathrm{IL}-1 \beta)\left(1.0 \mathrm{ng} \mathrm{m}^{-1}\right)$ on $\mathrm{LH}$-stimulated progesterone production by bovine luteal cells on day 7 of culture. Values are means \pm SEM ( $n=8$ corpora lutea). *Significantly different from control (Student's t-test, $P<0.01$ ).

dose-dependent increases in $\mathrm{PGF}_{2 \alpha^{\prime}} \mathrm{PGE}_{2}$ and 6-keto-PGF $\mathrm{P}_{1 \alpha}$ (the stable metabolite of prostacyclin). This stimulatory effect of IL-1 $\beta$ was completely blocked by indomethacin (Nothnick and Pate, 1990), cycloheximide or actinomycin D (Townson and Pate, 1994). The acute (6 h) stimulation of luteal prostaglandin production by IL-1 $\beta$ appears to be via activation of phospholipase $A_{2}$ and to a lesser extent, phospholipase C. Thus, a primary action of $I L-1 \beta$ is to increase availability of arachidonic acid for conversion to prostaglandins. After chronic $(72 \mathrm{~h})$ exposure to IL-I $\beta$, luteal cells exhibit an enhanced ability to convert exogenous arachidonic acid to $\mathrm{PGF}_{2 u}$, suggesting an upregulation of prostaglandin synthase (PGS) (Townson and Pate, 1994).

The actions of TNF- $\alpha$ on bovine luteal cells are very similar to those of IL-I $\beta$. Gonadotrophinstimulated steroidogenesis is suppressed and prostaglandin synthesis is stimulated by TNF- $\alpha$ (Benyo and Pate, 1992), TNF- $\alpha$ also activates phospholipase $A_{2}$, but not phospholipase C (D. H. Townson, and J. L. Pate, unpublished). An effect of TNF- $\alpha$ on PGS has not yet been demonstrated. When combined, TNF- $\alpha$ and IL-1 $\beta$ exert synergistic effects on luteal prostaglandin production (Benyo and Pate, 1992). TNF- $\alpha$. inhibits basal and gonadotrophin-stimulated progesterone secretion and enhances the inhibitory effects of PGF $\mathrm{Pa}_{2 a}$ and oxytocin in pig luteal cells (Pitzel et al., 1993). Therefore, all of the known effects of TNF- $\alpha$ on fully differentiated luteal cells are consistent with a role for this cytokine in luteal regression.

Another cytokine that is thought to be involved in luteolysis is IFN- $\gamma$. This cytokine exerts biphasic effects on cultured bovine luteal cells. During the first $24 \mathrm{~h}$ of culture, IFN- $\gamma$ has no effect on progesterone synthesis but inhibits prostaglandin production. After $72 \mathrm{~h}$, no difference is observed in either progesterone or prostaglandin secretion compared with control cells. However, after this time, IFN- $\gamma$ completely inhibits $\mathrm{LH}$-stimulated progesterone and markedly stimulates prostaglandin synthesis by these cells (Fairchild and Pate, 1991). Since PGF Pa $_{2 a}$ is known to inhibit LH-stimulated progesterone production in luteal cells in vitro (Pate and Condon, 1984), it was assumed that the inhibition of steroidogenesis by IFN- $\gamma$ was due to its stimulation of endogenous $\mathrm{PGF}_{2 \alpha}$. This possibility was tested by culturing luteal cells in the presence of indomethacin, at a concentration that completely prevented the IFN- $\gamma$-induced increase in prostaglandins. The assumption proved to be incorrect, because IFN- $\gamma$ was equally effective at inhibiting LH-stimulated progesterone in the presence or absence of indomethacin 


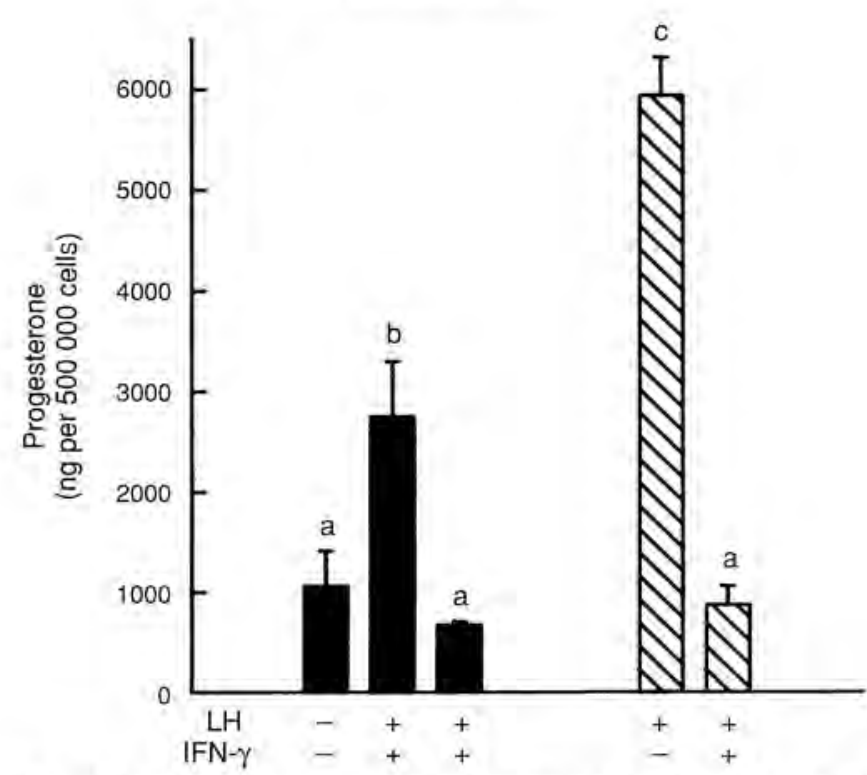

Fig. 2. Progesterone production by bovine luteal cells on day 7 of serum-free culture. Treatments consisted of gamma-interferon (IFN- $\gamma$ )

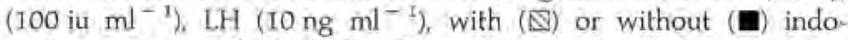
methacin $\left(10 \mu \mathrm{g} \mathrm{ml}^{-1}\right)$. Each value represents the mean $\pm \operatorname{sEM}(n=5$ corpora lutea) and bars with different superscripts are significantly different. (Reproduced with permission from Fairchild and Pate, 1991.)

(Fig. 2; Fairchild and Pate, 1991). Therefore, the ability of IFN- $\gamma$ to inhibit gonadotrophin-stimulated steroidogenesis does not depend on the increase in endogenous prostaglandins.

\section{Interactions between cytokines, luteal prostaglandins and progesterone}

If the stimulation of prostaglandin synthesis is not responsible for the inhibition of progesterone, then a question arises regarding the role of luteal prostaglandins. This question has been difficult to address using models in vito because of the many systemic effects of prostaglandins and the requirement for uterine $\mathrm{PGF}_{2 a}$ to initiate luteolysis. Cultured luteal cells also may not be an appropriate model to study this problem, because luteal prostaglandins may act on other cell types. Prostaglandins are known to be potent vasodilators or vasoconstrictors. The ability of $\mathrm{PGF}_{2 a}$ to decrease blood flow to the corpus luteum at the time of luteolysis has been studied (reviewed by Wiltbank, 1994). It is possible that uterine $\mathrm{PGF}_{2 \mathrm{c}}$ causes the initial fall in progesterone by acting directly on luteal cells, and luteal prostaglandins are then released which act on capillary endothelial cells to regulate blood flow. Another likely role for luteal prostaglandins is to alter the local immune response. Prostaglandins can modulate activation of immune cells and cytokine secretion. It is possible that immune cells within the corpus luteum must be exposed to prostaglandins to become activated and facilitate luteolysis. Macrophages will infiltrate a fully functional corpus luteum that has received an implant, but will remain in the corpus luteum only if PGF $_{2 i}$ is present to cause luteolysis (Hehnke et al, 1994). Although prostaglandins are generally thought to be proinflammatory compounds they can also suppress an immune response (Goodwin and Webb, 1980). Luteal prostaglandins may act to enhance the function of immune cells to promote luteal regression or modify the local immune response so that it does not extend into the surrounding ovarian tissues.

Although endogenous prostaglandins may not be directly involved in the inhibition of steroidogenesis, progesterone may modify cytokine-stimulated prostaglandin production. When cultured luteal cells are deprived of an exogenous source of cholesterol (such as lipoprotein), progesterone synthesis will decline with time in culture. If exogenous progesterone is added to the cultures to maintain progesterone 


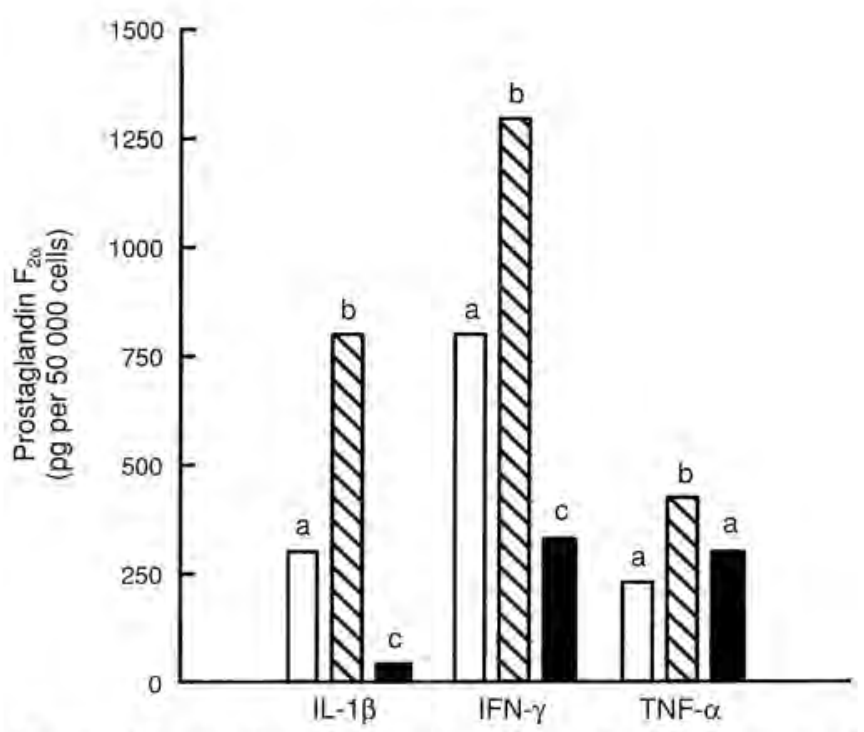

Fig. 3. Inhibition of cytokine stimulated prostaglandin production of cultured bovine luteal cells by progesterone $\left(5 \mu \mathrm{mol}^{-1}\right)$. Results for

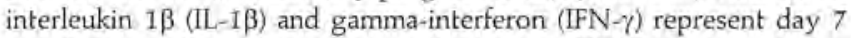
of culture, results for tumour necrosis factor- $\alpha$ (TNF- $\alpha$ ) represent $24 \mathrm{~h}$ of culture, Within each group, data were subjected to two-way. ANOVA followed by Student-Newman-Keul's post-test. $(\square)$ control; (\$) cytokine and (W) cytokine plus progesterone. Bars within a group with different letters are significantly different $(P<0.05)$. (Adapted with permission from Nothnick and Pate, 1990; Fairchild and Pate, 1991; and D. H. Townson and I. L. Pate, unpublished.)

concentrations equivalent to day 1 , it is possible to study the function of cells in a low (control) or normal (progesterone-supplemented) steroid environment. In this situation, progesterone suppresses basal prostaglandin production by luteal cells. More importantly, the high concentrations of progesterone inhibit IL-1 $\beta$-, IFN- $\gamma$ - and TNF- $\alpha$-stimulated prostaglandin production (Fig. 3). It is well known that gonadal steroids are important modulators of the immune response, and progesterone is usually immunosuppressive. In addition to direct suppression of immune cell activation, high local concentrations. of progesterone may also suppress responsiveness of target cells to cytokines. This could explain why cultured luteal cells are more responsive to IFN- $y$ later in culture. In addition, the action of cytokines on luteal cells in vivo may be suppressed when the corpus luteum is fully functional. When progesterone concentrations begin to decline, this suppression would be released, allowing luteal cells to become responsive to cytokines. This hypothesis is currently being tested in our laboratory.

\section{Cytotoxic actions of cytokines on luteal cells}

Certain cytokines also have direct cytotoxic effects on cells. Tumour necrosis factor was named for its ability to induce haemorrhagic necrosis of tumours. However, it does not generally cause cytolysis of normal cells. Although IL-I is not usually a cytotoxic agent, it can be cytotoxic to ovarian cells in culture (Ellman et al., 1993). In bovine luteal cells, neither IL-1 $\beta$ nor TNF- $\alpha$ affect cell viability when used alone (Nothnick and Pate, 1990; Benyo and Pate, 1992). Some loss of cell viability does occur when cells are treated with IFN- $\gamma$ (Fairchild and Pate, 1991; Benyo and Pate, 1992). However, marked cytotoxic effects were observed when TNF- $\alpha$ and IFN $-\gamma$ were used together (Fig. 4; Benyo and Pate, 1992). The combination of TNF- $\alpha$ and IFN- $\gamma$ is also cytotoxic to pancreatic $\beta$-islet cells (Campbell et al., 1988) and to thyroid cells (Weetman and Rees, 1988). In non-endocrine cells, the cytotoxic effect of TNF- $\alpha$ can be 


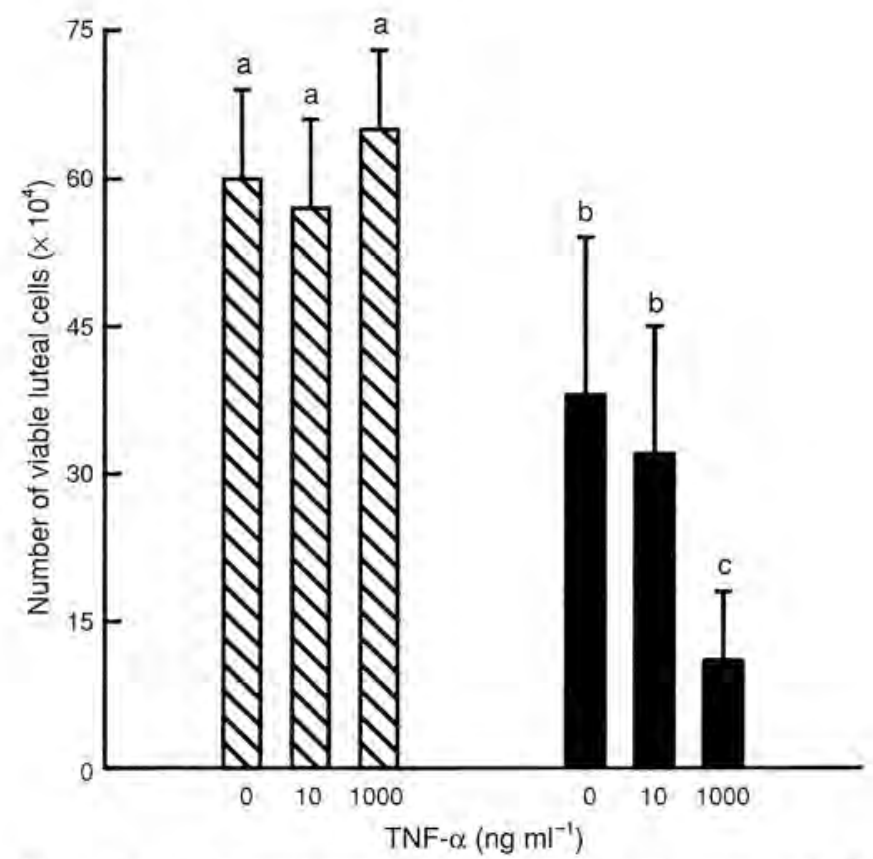

Fig. 4. Effect of tumour necrosis factor $\alpha$ (TNF- $\alpha)\left(0-1000 \mathrm{ng} \mathrm{ml}^{-1}\right)$ on the number of bovine luteal cells maintained on day 7 of serum-free culture. Cells were cultured in the absence ( $\mathbb{Q}$ ) or presence (1) of gamma-interferon (IFN- $\gamma$ ) (100 iu $\mathrm{ml}^{-1}$ ). Each value represents the mean \pm SEM ( $n=4$ corpora lutea) and bars with different letters are significantly different. (Reproduced with permission from Benyo and Pate, 1992; (C)The Endocrine Society.)

enhanced by IFN- $\gamma$ (Dealtry et al., 1987). Both of these cytokines enhance expression of receptors for the other cytokine, which could explain why both are necessary to achieve a substantial cytotoxic effect in many types of cell.

The mechanisms by which TNF- $\alpha$ and IFN- $\gamma$ exert cytotoxic effects on luteal cells are not known. In some ovarian cells, IL-I $\beta$ is cytotoxic, and its effects appear to be mediated by nitric oxide (Ellman et al., 1993). However, measurable increases in nitric oxide have not yet been observed during TNF- $\alpha$ and IFN- $\gamma$-induced death of luteal cells (M. L. Greene and J. L. Pate, unpublished). In other types of cell, the cytotoxic effect is mediated by either arachidonic acid metabolites, by generation of free oxygen radicals, or by activation of phospholipase $\mathrm{A}_{2}$ without subsequent metabolism of arachidonic acid (Suffys et $a l$, 1991). The cytolytic action of TNF- $\alpha$ and IFN- $\gamma$ on luteal cells is not clear. Inhibition of arachidonic acid metabolism or phospholipase $\mathrm{A}_{2}$ activity does not prevent TNF- $\alpha$ and IFN- $\gamma$-induced cytolysis (J. L. Pate and M. L. Greene, unpublished). It is possible that these cytokines work by increasing local concentrations of reactive oxygen species or, alternatively, by enhancing luteal cell sensitivity to oxygen toxicity (Marcho et al., 1991). During luteolysis in rats, there is an increase in superoxide radicals and hydrogen peroxide, and hydrogen peroxide inhibits cholesterol transport and gonadotrophin-stimulated steroidogenesis in rat luteal cells (reviewed by Behrman et al., 1993). Behrman et al. (1993) presented a model in which reactive oxygen species are intimately involved in luteolysis. Although the effects of reactive oxygen species on progesterone production are not due to cytotoxicity, it is possible that chronic exposure of luteal cells to $\mathrm{H}_{2} \mathrm{O}_{2}$ or $\mathrm{O}_{2}{ }^{-}$in the presence of cytokines results in eventual membrane damage and cell death. At this time, the mechanisms by which cytokines induce functional changes in luteal cells are at least partly known, but the mediators of their cytotoxic actions have remained elusive. A summary of the effects of cytokines on luteal cells is presented in Fig. 5 . 


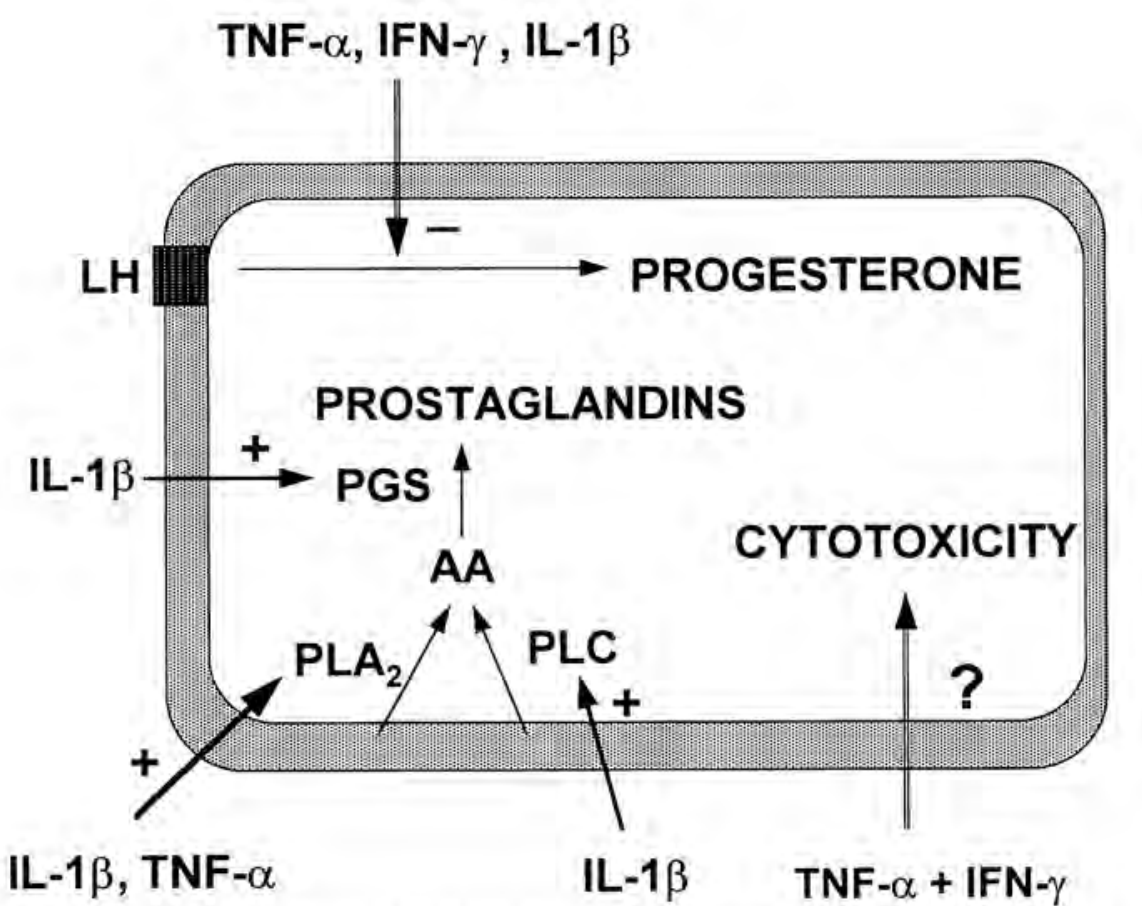

Fig. 5. Schematic illustration of cytokine actions on luteal cells. Tumour necrosis factor- $\alpha$ (TNF- $\alpha$ ), gamma-interferon (IFN- $\gamma$ ), and interleukin I $\beta$ (IL-1 $\beta$ ) all inhibit L.H-stimulated progesterone. These three cytokines also increase luteal prostaglandin synthesis: IL-1 $\beta$ primarily acts by activating phospholipase $A_{2}\left(P L A_{2}\right)$ to release arachidonic acid (AA) from membrane phospholipids, but can also activate phospholipase $C$ (PLC) and prostaglandin synthase (PGS). In contrast, TNF- $\alpha$ has been demonstrated only to

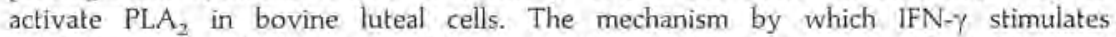
prostaglandin synthesis is not yet known. When administered concurrently, TNF- $\alpha$ and IFN- $\gamma$ also have a cytotoxic effect on luteal cells, which is independent of the stimulation of prostaglandin synthesis. The intracellular mediators of cytokine-induced cytoxicity have not yet been elucidated.

\section{Activation of Immune Cells in Luteolysis}

If immune cells and their secreted products are involved in luteal regression, there must be a trigger that activates the immune cells. As mentioned previously. $T$ cells are activated by recognition of an MHC-associated antigenic peptide and exposure to sufficient concentrations of appropriate cytokines. Nearly all nucleated cells express MHC class I glycoproteins, which are recognized by cytotoxic T cells. MHC class II molecules are recognized by $T_{H}$ cells, which secrete cytokines that activate $T_{C}$ cells. MHC class Il molecules are normally expressed only on antigen-presenting cells, such as macrophages and B cells. However, aberrant expression of MHC class II molecules can occur in pathogenesis, and may be an underlying cause in certain autoimmune endocrine disorders (Bottazzo et al, 1983). We suggested that the trigger for an immune response in luteolysis might be an alteration in, or aberrant expression of, MHC glycoproteins on the luteal cell surface. Cultured bovine luteal cells were used to determine that luteal cells did express MHC class I molecules, as expected, and there was very little expression of MHC class II molecules. Treatment with either TNF- $\alpha$ or IFN- $\gamma$ for $72 \mathrm{~h}$ resulted in a slight, but significant, increase in MHC class I glycoproteins (Fairchild and Pate, 1991; Benyo and Pate, 1992). High class I expression could promote cytotoxic $T$ cell actions against luteal cells. Of greater interest was the profound induction of MHC class II molecules on luteal cells by IFN- $\gamma$ (Fairchild and Pate, 1989). This could allow for autoantigen recognition by helper $\mathrm{T}$ cells and stimulation of cytokine production. In the 


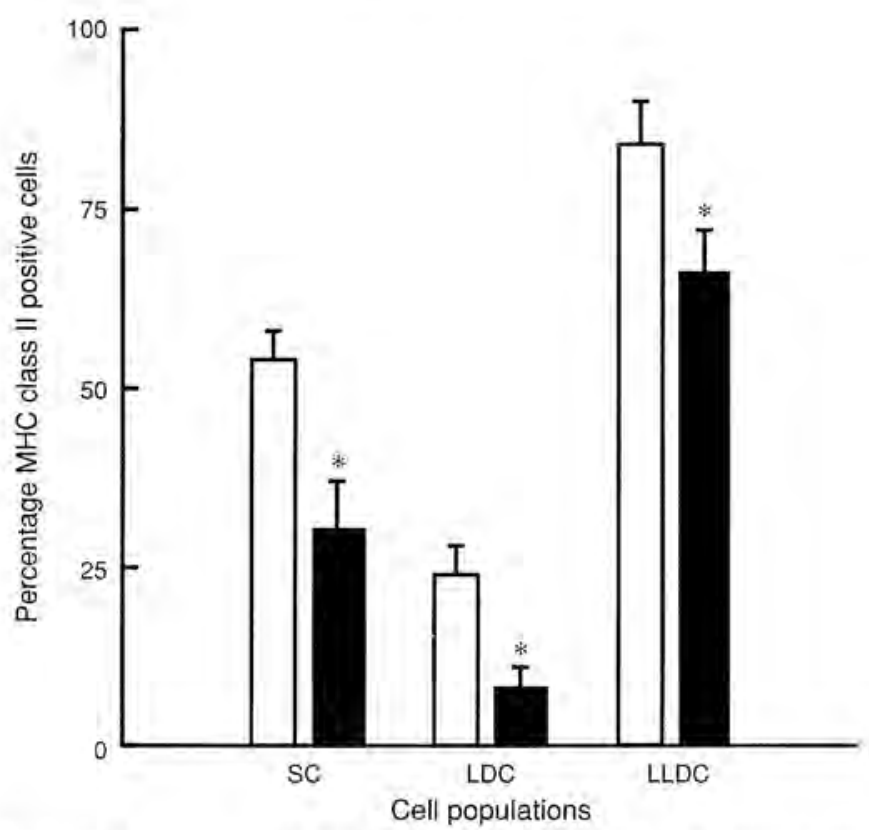

Fig. 6. Expression of MHC class II molecules on cell populations comprising corpora lutea on days $18-20$ of the oestrous cycle ( $\square$ ) or days 18-2I of pregnancy (- SC: small luteal cells; LDC: large, dense cells; LLDC: large, less dense cells. The density of cells is a reflection of cell granularity. Each value represents the mean $\pm \operatorname{SEM}(n=4$ corpora lutea per group). *Significant differences within cell populations between nonpregnant and pregnant animals. (Reproduced with permission from Benyo et al., 1991.)

same study, stimulation of luteal cells with LH resulted in a slight, but significant, suppression of IFN- $\gamma$-induced expression of MHC class II glycoproteins. The potential relevance of expression of MHC molecules on bovine luteal cells was evaluated using freshly dispersed luteal cells from corpora lutea collected at three stages of the oestrous cycle. There were no observable changes in expression of class I glycoproteins throughout the lifespan of the corpus luteum. In the early corpus luteum (day 6), expression of MHC class II molecules was low. However, by day 10, nearly $80 \%$ of the large, less dense luteal cells displayed class II glycoproteins. Small luteal cells exhibited increased expression by day I8 of the oestrous cycle. Increased expression was also observed in small and large luteal cells during $\mathrm{PGF}_{2 \mathrm{u}}$-induced luteolysis (Benyo et al, 1991). Similar patterns of expression have also been observed in the sheep corpus luteum during the oestrous cycle (Kenny et al., 1991), supporting the notion that these glycoproteins have a functional significance in regulation of the corpus luteum of ruminants. In human ovaries, an MHC class II protein was present on granulosa cells of atretic follicles and on luteinizing granulosa cells (Fujiwara et al., 1993), and these authors concluded that this molecule may serve as a marker for differentiation of ovarian cells.

It is presumed that expression of MHC class II glycoproteins on the surface of luteal cells confers the function of antigen presentation to these cells. If this is the case, luteal cells would present an autoantigen to $\mathrm{T}$ cells, which could result in an immune response against the corpus luteum. The presence or identity of an autoantigen presented by luteal cells remains to be determined. Expression of MHC class II molecules on luteal cells may also activate different components of the immune system than is typically observed. In epithelial cells, expression of MHC class II molecules may activate cytotoxic T cells rather than helper T cells (Bland, 1988). Alternatively, the MHC molecules on luteal cells could serve another role, unrelated to activation of immune cells. They may serve as differentiation antigens (Fujiwara et al., 1993) or to present differentiation-stage specific peptides (Harris et al.; 1993). There is some evidence 


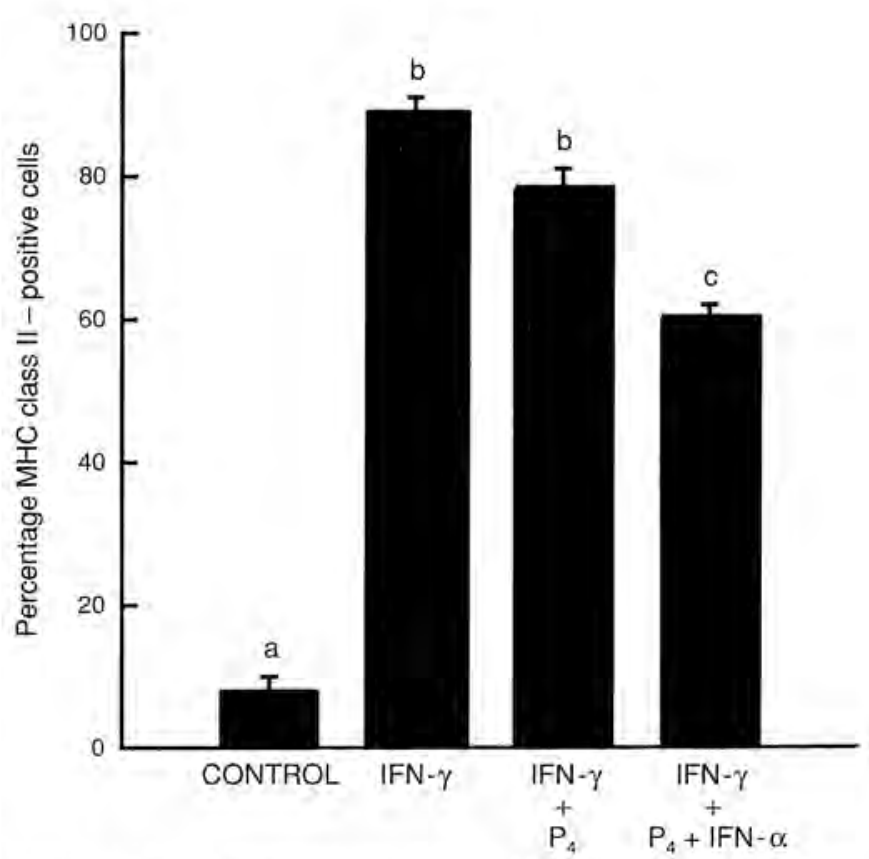

Fig. 7. Effect of progesterone $\left(5 \mu \mathrm{mol} \mathrm{\textrm {I } ^ { - 1 }}\right)$ and progesterone plus alpha-interferon (IFN- $\alpha$ ) on IFN- $\gamma$-induced MHC class II molecules on cultured bovine luteal cells. Control cultures received no cytokine, all other cultures received IFN- $\gamma$ at a concentration known to stimulate expression of MHC class II molecules. Bars with different superscripts are significantly different $(P<0.05)$ (D. F. Benyo and J. L. Pate. unpublished).

that MHC molecules can associate with cell surface receptors, perhaps altering responsiveness of the cell to protein hormones or growth factors (Solano et al., 1988; Hsu and Olefsky, 1993). It has also been suggested that the MHC molecules expressed by epithelial cells are present in a different conformation from those expressed on conventional antigen-presenting cells, which may be an indication of a distinct function for these molecules (Vidal et al, 1993).

If immune cells are involved in the luteolytic process, it would be necessary for this immune response to be suppressed during maternal recognition of pregnancy. Certainly, alterations in normal immune response mechanisms occur in the placenta to allow for survival of the fetal allograft. It is possible that an immunological process involved in luteolysis would be altered concurrently with the establishment of pregnancy. This hypothesis is supported by the observations that infiltration of lymphocytes and macrophages in the bovine (Lobel and Levy, 1968) and rabbit (Bagavandoss et al., 1990) corpus luteum of pregnancy does not occur to the same extent as in the corpus luteum of the oestrous cycle. In addition, expression of $\mathrm{MHC}$ class II glycoproteins is significantly decreased on all luteal cell populations in pregnant compared with nonpregnant cows (Fig. 6, Benyo et al., 1991) and sheep (Kenny et al., 1991). The signal for suppression of expression of MHC molecules is not known, but may be related to the trophoblastic protein, IFN- $\tau$. In cultured luteal cells, IFN- $\alpha$, which has biological properties similar to IFN- $\tau$, can suppress TNF- $\alpha$ - or IFN- $\gamma$-stimulated prostaglandin production (Benyo and Pate, 1992; J. L. Pate, unpublished). In the presence of high concentrations of progesterone, as would be seen in early pregnancy, IFN- $\alpha$ also suppresses induction of MHC class II glycoproteins by IFN- $\gamma$ (Fig. 7, D. F. Benyo and J. L. Pate, unpublished). Therefore, at the time of trophoblastic secretion of IFN- $\tau$, maternal recognition of pregnancy may be further ensured by a similar signal to the ovary to increase local concentrations of an IFN- $\alpha$-like protein. 


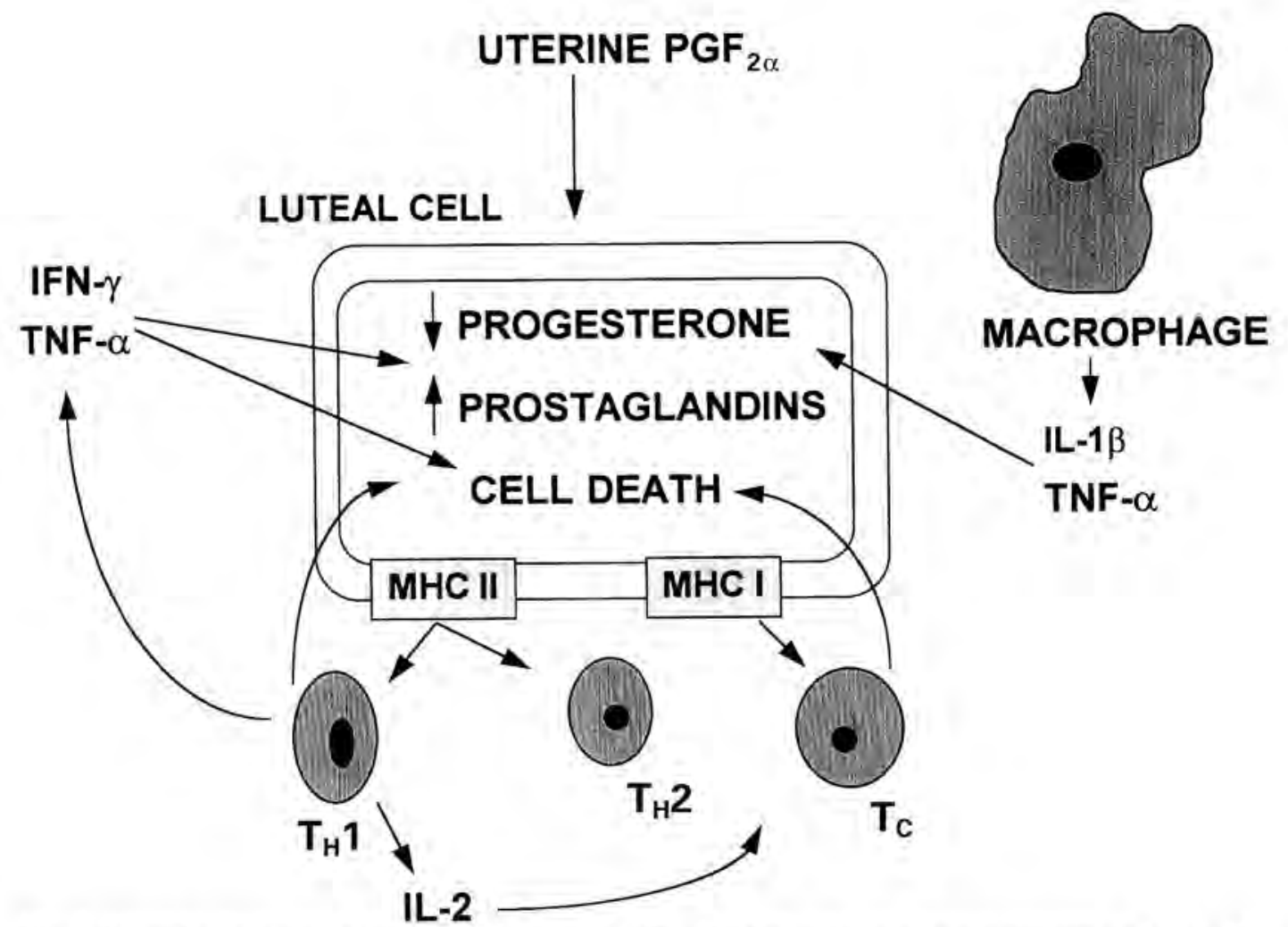

Fig. 8. Schematic illustration of interactions of immune cells with luteal cells. Luteolysis in ruminants is initiated by uterine release of $\mathrm{PGF}_{z,}$, which inhibits progesterone production. Late in the oestrous cycle, $\mathrm{MHC}$ class II glycoproteins and MHC class 1 glycoproteins are expressed on the surfaces of luteal cells. Expression of MHC molecules facilitates activation of $T$ cells, such as cytotoxic $T$ cells $\left(T_{C}\right)$ and helper $T$ cells $\left(T_{H^{1}}\right.$ and $\left.T_{H^{2}}\right)$. When activated. $T_{H} 1$ cells can produce interleukin-2 (IL-2), gamma-interferon (IFN- $\gamma$ ) and tumour necrosis factor $\alpha$ (TNF- $\alpha$ ). Cytokines can also be produced by $T_{H} 2$ and $T_{C}$ cells, but are not shown here. Activation of $T_{H}$ and $T_{C}$ cells is further enhanced by IL-2. Resident macrophages, which may be activated by IFN- $\gamma$, secrete IL-I $\beta$ and TNF- $\alpha$. Cytokines can act directly to affect luteal cell function. Progesterone production is suppressed by IFN- $\gamma$, TNF- $\alpha$ and IL-1 $\beta$. In addition, these cytokines stimulate prostaglandin production by luteal cells, which may, in turn, act directly on luteal cells or immune cells. Finally, IFN- $\gamma$ and TNF- $\alpha$ exert cytotoxic effects on luteal cells. Cell death may also be brought about by the actions of $\mathrm{T}_{C}$ or $\mathrm{T}_{\mathrm{H}} 1$ cells, and dead cells are phagocytozed by activated macrophages.

\section{Conclusions}

Considerable evidence is accumulating that cytokines can exert functional and cytotoxic effects on luteal cells. Furthermore, immune cells are present in the corpus luteum before luteolysis and some cytokines have been detected within luteal tissue. However, the exact role of immune cells and cytokines in luteal regression is still not clear. Treating rabbits with methylprednisolone to deplete luteal $T$ cells and macrophages did not prevent the normal decline in progesterone at the end of pseudopregnancy (Seiner et al., 1992). In contrast, treating rats with dexamethasone did block luteolysis, in uterine-intact and in hysterectomized animals (Wang et al, 1993). Experiments in vivo that can test the role of immune cells in luteolysis have not been performed in ruminants. In addition, it has been difficult to evaluate the presence of cytokines in ovarian tissues, because not all available assays crossreact with the ruminant proteins. Some cytokines, such as interferons, are highly species specific with regard to both their immunoreactivity and biological activity. The evidence from models in vitro and some experiments in vivo has provided a framework for the interactions of immune cells with luteal cells. These are shown in Fig. 8. The functional significance of immune cells and cytokines in 
regulating the ruminant oestrous cycle will be determined in future experiments where these factors can be manipulated in vivo.

\section{References}

Abbas AK, Williams ME, Burstein HJ, Chang T-L, Bossu P and Lichtman AH (1991) Activation and functions of CD4 + T-cell subsets lmmunological Reviews 123 5-22

Bagavandoss P, Kunkel SL, Wiggins RC, and Keyes PL (1988) Tumor necrosis factor (TNF- $\alpha$ ) production and localization of macrophages and $T$ lymphocytes in the rabbit corpus luteum Endocrinology 122 1185-1187

Bagavandoss P, Wiggins RC, Kunkel SL, Remick DG and Keyes PL (1990) Tumor necrosis factor production and accumulation of inflammatory cells in the corpus luteum of pseudopregnancy and pregnancy in rabbits Biology of Reproduction 42 367-376

Behrman HR, Endo T, Aten RF and Musicki B (1993) Corpus luteum function and regression Reproductive Medicine Review 2 153-180

Benyo DF, and Pate IL (1992) Tumor necrosis factor-a alters bovine luteal cell synthetic capacity and viability Endocrinology $130854-860$

Benyo DF, Haibel GF, Laufman HB and Pate IL (1991) Expression of major histocompatibility complex antigens on the bovine corpus luteum during the estrous cycle, luteolysis, and early pregnancy Biology of Reproduction $\mathbf{4 5}$ 229-234

Bland P (1988) Major histocompatibility Class Il expression by the gut epithelium Immunology Todny 9 174-178

Bottazzo GF, Pajol-Borrel R, Hanafusa T and Feldman R (1983) Role of aberrant HLA-DR expression and antigen presentation in induction of endocrine autoimmunity Lancet ii $1115-1118$

Brannstrom M and Norman RJ (1993) Involvement of leukocytes and cytokines in the ovulatory process and corpus luteum function Human Reproduction 8 1762-1775

Brannstrom M. Wang L and Norman RJ (1993a) Ovulatory effect of interleukin-1 $\beta$ on the perfused rat ovary Endocrinology $132 \quad 399-404$

Brannstrom M, Wang L and Norman RJ (1993b) Effects of cytokines on prostaglandin production and steroidogenesis of incubated preovulatory follicles of the rat Biology of Reproduction 48 165-171

Brannstrom M, Giesecke L, van den Heuvel C]. Moore IC and Robertson SA (1994a) Leukocyte subpopulations in the rat: corpus luteum during pregnancy and pseudopregnancy Biology of Reproduction 50 1161-1167

Brannstrom M, Norman RJ, Seamark RF and Robertson SA (1994b) Rat ovary produces cytokines during ovulation Biology of Reproituction 50 88-94

Bukovsky A, Presl J, Krabec Z and Bednarik T (1977) Ovarian function in adult rats treated with antithymocyle serum Experientia 33 280-281

Campbell IC, Iscaro A and Harrison LC (1988) IFN $-\gamma$ and TNF- $\alpha$, Cytotoxicity to murine islets of Langerhans Joumal of Immunology $1412325-2329$

Cavender IL and Murdoch WJ (1988) Morphological studies of the microcirculatory system of periovulatory ovine follicles Biology of Reproduction $39989-997$

Darbon JM, Oury F, Laredo J and Bayard F (1989) Tumor necrosis factor- $\alpha$ inhibits folicle stimulating hormone- induced differentiation in cultured rat granulosa cells Biochemical and Biophysical Research Communications 163 $1038-1046$

Dealtry GB, Naylor MS, Fiers W and Balkwill FR (1987) DNA fragmentation and cytotoxicity caused by tumor necrosis factor is entanced by interferon- $\gamma$ European Journal of Immunology 17 689-693

Ellman C, Corbett JA, Misko TP, McDaniel M and Beckerman KP (1993) Nitric oxide mediates interleukin-1-induced cellular cytotoxicity in the rat ovary Journal of Clinical Investigation $923053-3056$

Emi N, Kanzaki H, Yoshida M, Takakura K, Kariya M, Okamoto N, Imai K and Mori T (1991) Lymphocytes stimulate progesterone production by cultured human granulosa luteal cells Americam Joumal of Obstertics and Gynecology 165 1469-1474

Fairchild DL and Pate Л (1989) Interferón-gamma induction of major histocompatibility complex antigens on cultured bovine luteal cells Biology of Reproduction 40 $453-457$

Fairchild DL and Pate IL (199I) Modulation of bovine luteal cell synthetic capacity by interferon-gamma Biology of Repro. duction $44357-363$

Fujiwara H, Ueda M, Imai K, Fukuoka M, Yasuda K, Takakura K, Suginami H, Kanzaki $\mathrm{H}$, Inoka $\mathrm{H}$, Mori $\mathrm{T}$ and Maeda $\mathrm{M}$ (1993) Human leukocyte antigen-DR is a differentiation antigen for human granulosa cells Biology of Reproduction $49705-715$

Goodwin JS and Webb DR (1980) Regulation of the immune response by prostaglandins Clinical Immunology and Immunopathology 15 106-122

Gorospe WC, Tuchel T and Kasson BS (1988) $\gamma$-Interferon inhibits rat granulosa cell differentiation in culture Biochemical and Biophysical Research Communications 157 $891-897$

Gottschall PE, Vehara A, Talbot Hoffman S and Arimura A (1987) Interleukin-1 inhibits follicle-stimulating hormone induced differentiation in rat granulosa cells in vifro Biochemical and Biophysical Research Communications 149 502-509

Harris PE, Lupu F, Hong B, Reed EF and Suciu-Foca N (1993) Differentiation-stage specific self-peptides bound by major histocompatibility complex class 1 molecules Journal of Experimental Medicine 177 783-788

Hehnke KE, Christenson LK, Ford SP and Taylor MJ (1994) Macrophage infiltration into the porcine corpus luteum

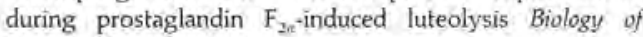
Reproduction 50 10 -15

Hellberg P. Thomsen P, Janson PO and Brannstrom M (1991) Leukocyte supplementation increases the luteinizing hormone-induced ovulation rate in the in vitro-perfused rat ovary Biology of Reproduction 44 791-797

Hill JA and Anderson DJ (1990) Evidence for the existence and significance of immune cells in male and female reproductive tissues Immunology and Allergy Clinics of North America $101-12$ 
Hsu D and Olefsky JM (1993) Effect of a major histocompatibility complex class I peptide on insulin-like growth factor-I receptor internalization and biological signaling Endocrinology 133 1247-1251

Hughes FM, Pringle CM and Gorospe WC (1991) Production of progestin-stimulatory factor(s) by enriched populations of rat $\mathrm{T}$ - and B-lymphocytes Biology of Reproduction 44 922-926

Hunt JS, Chen H, Hu X and Tabibzadeh S (1992) Tumor necrosis factor- $\alpha$ messenger RNA and protein in human endometrium Biology of Reproduction 47 141-147

Hunt JS, Chen HL, Hu XI and Pollard JW (1993) Normal distribution of tumor necrosis factor- $\alpha$ mRNA and protein in the uteri, placentas, and embryos of osteoporotic mice lacking CSF-I Biology of Reproduction 49 441-452

Ji T, Slaughter RG. Ellis JA. Ji TH and Murdoch WJ (1991) Analyses of ovine corpora lutea for tumor necrosis factor mRNA and bioactivity during prostaglandin-induced luteolysis Molecular Cell Endocrinology 81 77-80

Kenny N, Herman JR, Barisas BG and Roess DA (1991) Flow cytometric analysis of Class $\mathrm{I}$ and II MHC antigens on ovine luteal cell types. In Signaling Mechanisms and Gene Expression in the Ovary pp 467-472 Ed. G. Gibori. SpringerVerlag, New York

Lobel BL and Levy E (1968) Enzymatic correlates of development, secretory function and regression of follicles and corpora hutea in the bovine ovary II; formation, development and involution of corpora lutea Acka Endocrinology 59 (Supplement 132) 35-51

Marcho Z, White JE, Higgins PJ and Tsan M (I991) Tumor necrosis factor enhances endothelial cell susceptibility to oxygen toxicity; role of glutathione American Journal of Respiratory, Cellular, and Molecular Biology 5 556-562

Murdoch WJ and McCormick RJ (1989) Production of low molecular weight chemoattractants for leukocytes by periovulatory ovine follicles Biology of Reproduction 41 86-90

Nakamura Y. Kato H and Terranova PF (1990) Interleukin-J $\alpha$ increases thecal progesterone production of preovulatory follicles in cyclic hamsters Biology of Reproduction 43 169-173

Nothnick WB and Pate JL. (1990) Interleukin-1 $\beta$ is a potent stimulator of prostaglandin synthesis in bovine luteal cells Biology of Reproduction 43 898-903

Pate IL (1994) Cellular components involved in luteolysis Journal of Animal Science 72 1884-1890

Pate JL and Condon WA (1984) Effects of prostaglandin $\mathrm{F}_{2 \mathrm{a}}$ on agonist-induced progesterone production in cultured bovine luteal cells Biology of Reproduction 31 427-435

Pate JL and Townson DH (1994) Novel local regulators in luteal regression Journal of Animal Science 72 (Supplement 3) $31-42$

Pitzel L, Jarry H and Wuttke W (1993) Effects and interactions of prostaglandin $\mathrm{F}_{20}$ oxytocin and cytokines on steroidogenesis of porcine luteal cells Endocrinology 132 751-756

Roby KF and Terranova PF (1989) Localization of tumor necrosis factor (TNF) in the rat and bovine ovary using immunocytochemistry and cell blot: evidence for granulosal production. In Growth Factors and the Ovary pp 273-278 Ed. AN Hirshfield. Plenum Press, New York
Roby KF and Terranova PF (1990) Effects of tumor necrosis factor- $\alpha$ in vitro on steroidogenesis of healthy and atretic follicles of the rat: theca as a target Endocrinology 126 2711-2718

Sapolsky RM, Rivier C, Yamamoto G, Plotsky P and Vale W (1987) Interleukin-I stimulates the secretion of hypothalamic corticotropin-releasing factor Science 238 $522-524$

Seiner SJ, Schramm W, and Keyes PL (1992) Effect of treatment with methylprednisolone on duration of pseudo-pregnancy and on macrophages and $\mathrm{T}$ lymphocytes in rabbit corpora lutea Journal of Reproduction and Fertility 96 347-353

Smith MF, McIntosh EW and Smith GW (1994) Mechanisms associated with corpus luteum development Joumal of Animal Science 72 I857-1872.

Solano AR, Sanchez ML, Sandanons ML, Dada L and Podesta EJ (1988) Luteinizing hormone triggers a molecular association between its receptor and the MHC class 1 antigen to produce cell activation Endócrinology 122 2080-2083

Spicer LJ and Alpizar E (1994) Effects of cytokines on FSHinduced estradiol production by bovine granulosa cells in vitro: dependence on size of follicle Domestic Animal Endocrinology 11 25-34

Standaert FE, Chew BP and Wong TS (1990) Influence of blood monocytes and lymphocytes on progesterone production by granulosa cells from small and large follicles in the pig American Joumal of Reproductive Immunology 22 49-55

Suffys P, Beyaert R, De Valck D, Vannhaesebroeck B, Van Roy F and Fiers W (1991) Tumor necrosis factor mediated cytotoxicity is correlated with phospholipase $A_{2}$ activity, but not with arachidonic acid release per se Earopean Joumal of Biochemistry $195-465-475$

Townson DH and Pate IL (1994) Regulation of prostaglandin synthesis by interleukin-1 $\beta$ in cultured bovine luteal cells Biology of Reproduction $\mathbf{5 1}$ 480-485

Vidal K, Samarut C, Magaud J-P, Revillard J-P and Kaiserlian D (1993) Unexpected lack of reactivity of allogeneic anti-la monoclonal antibodies with MHC class II molecules expressed by mouse intestinal epithelial cells Joumal of immunology $1514642-4650$

Wang F, Riley JGM, and Behrman HR (1993) Immunosuppressive levels of glucocorticoid block extrauterine huteolysis in the rat Biology of Reproduction 49 66-73

Weetman AP and Rees AJ (1988) Synergistic effects of recombinant tumor necrosis factor and IFN-garnma on rat thyroid cell growth and la antigen expression lmmunolagy 63 285-290

Wiltbank MC (1994) Cell types and hormonal mechànisms associated with mid-cycle corpus luteum function Joumal of Animal Science 72 1873-1883

Yan Z, Hunter V, Weed J, Hutchison S, Lyles R and Terranova P (1993) Tumor necrosis factor-a alters steroidogenesis and stimulates proliferation of human ovarian granulosal cells in vitro Fertility and Sterility $59332-338$

Ziltener HJ, Maines-Bandiera S, Schrader JW and Auersperg N (199.3) Secretion of bioactive IL-1, IL-6 and CSFs by human ovarian surface epithelium Biology of Reproduction $\mathbf{4 9}$ $635-641$ 